\title{
IMPACT OF ONLINE TRAVEL AGENCIES ON HOTEL BUSINESS IN BOSNIA AND HERZEGOVINA
}

\author{
Lejla Ahmić ${ }^{1}$ \\ Almir Peštek ${ }^{2}$ \\ Lejla Turulja $^{3}$
}

\begin{abstract}
New online trends have been changing the global tourism market, making it highly competitive and complex, and therefore hotels are faced with many challenges in doing their business and attracting guests. Online travel agencies (OTA) as intermediaries on the tourism market have a huge impact on operations of hotels worldwide. The aim of this study was to explore the impact of OTAs on hotel business in Bosnia and Herzegovina. An online study was conducted on a sample of 58 hotels (out of 100 planned to be involved) in November 2014. A structured questionnaire based on studies of Caliskan et al. (2013) and Sisko (2013) was used. The results of the study show that the hotels in Bosnia and Herzegovina have adapted to global tourism trends and cooperate with OTAs, especially with Booking.com and Expedia.com. Most hotels simultaneously cooperate with more than one OTA. Although the costs of cooperation with OTAs were considered to be high, they generate most of bookings for the hotels. Therefore, OTAs are recognized as generators of sales and revenues from standard hotel services and creators of their competitive position. At the same time, cooperation with OTAs does not lead to a significant decrease of costs.
\end{abstract}

Key words: hotels, online travel agencies, Bosnia and Herzegovina

\section{INTRODUCTION}

As a trend characterizing the modern society, globalization is reflected in the increasing interdependence and connectedness of all parts of the world. Most authors argue that globalization is a result of the impact of the development of information and communication technologies (ICT) (Sagi, 2004), above all the Internet. Trends of business globalization and internationalization, development of infrastructure and modern technology affect the development of tourism industry.

The development of tourism industry directly affects the increase of opportunities for the business of service enterprises, where hotels have a significant position. Over the past few years, product distribution over the Internet has become one of the fastest-growing distribution methods. Since the introduction of online booking with payment in 1996, when the first online booking and air ticket payment was made, the Internet has introduced a revolution in the tourism distribution system (Gursoy, 2010). Despite hotels' initial hesitation about adopting information technologies, they have made great efforts over the past few years in order to implement electronic distribution in their own distribution systems. This strategy allowed hotels to make use of strengths of the two main directions:

1 Graduate student, School of Economics and Business Sarajevo, Sarajevo, Bosnia and Herzegovina.

2 Associate Professor, Department of Marketing, School of Economics and Business Sarajevo, Sarajevo, Bosnia and Herzegovina.

${ }^{3}$ Senior Teaching Assistant, Department of MIT, School of Economics and Business Sarajevo, Sarajevo, Bosnia and Herzegovina. 
1. The Internet gave hotels the opportunity to market their services, as well as to advertise online, thus using a cheaper distribution system (Morosan and Jeong, 2007) $\mathrm{i}$

2. The Internet created possiblities for hotels to reduce investment into mass advertising and allowed them to concentrate on the tailored marketing messages.

New trends in online booking are changing the online tourism market and the hotel industry is daily becoming increasingly competitive and complex. New technologies allow users to visit websites of hotels and intermediaries and thus get many benefits, such as: comparison of various destination prices by different criteria, possibility to combine offers, rating services and hotel facilities by guests, etc.

Based on the above-described, and taking into account the theoretical framework of the paper, which clearly points to the increasing significance of online distribution channels in contemporary hotel industry and to the cooperation with online intermediaries, the subject of this research includes the analysis and identification of online travel agencies' contribution to the business and profitability of hotels in Bosnia and Herzegovina.

The paper is structured as follows. First, we analyze the concepts of distribution channels in tourism. Thereupon, we propose and test hypotheses on the correlation between the cooperation of hotels and online travel agencies and their business performance. Finally, we discuss our findings and implications, and give suggestions for future research.

\section{LITERATURE REVIEW}

Determining the best approach to product delivery to the market was one of the greatest challenges merchants faced since early days of market establishment (Connolly, 1999). Distribution is part of the marketing function in the organization, which makes products and services accessible and available to consumers and provides a link between supply and demand. Together with the other three components of the marketing communication mix, i.e. product, price and promotion, distribution is a critical aspect of the strategic marketing management, with the general aim of satisfying consumers' needs. Distribution is one of the most important factors and one of the fundamental company activities, which affects the competitive ability of any business.

In tourism, distribution is a link between suppliers, destination and consumers in the market. In tourism organisations, as opposed to manufacturing ones, the focus is on service, as a non-material product. The travel products, as well as packages, are not always marketed by the product producer, and therefore intermediaries play a significant role in the distribution system, since they are a link between suppliers and consumers. Since products in tourism are non-material, consumers buy only expectation, since products cannot be shown to the consumer, and we can thus say that companies market only information. Traditionally, hospitality industry products were distributed through direct sales, as well as through intermediaries such as travel agencies, global distribution system, central booking system, etc. (Gursoy, 2010). However, market trends such as continuous consolidation, globalization together with ICT development created new possibilities for the distribution of hospitality industry products ( $\mathrm{O}^{\prime}$ Connor and Frew, 2004). Tourism distribution can be understood at two levels, i.e. as basic and expanded distribution. The basic distribution refers to the intermediary activity, which includes linking buyers to sellers. The expanded distribution, on the other hand, besides the basic intermediary activities, also refers to additional creation of value by intermediaries. Providing value in terms of service, price, availability, information or security is crucial for attracting 
consumers and their retention (Bigne, 2011). For this reason, we can list the following primary functions of distribution in tourism: information, combination and travel arranging services (Pearce, 2007). Many tourism distribution channels provide information for potential tourists, a group of tourism products and also allow customers to make and pay for bookings (Buhalis i Laws, 2008). Present studies have shown that various attempts have been made to define the concept of tourism distribution channels. Buhalis (2000) defines distribution channels as ,any organized and service system, created or used for providing suitable points of sale and/or approach to consumers, far from the place of production and consumption."

\section{RESEARCH HYPOTHESES}

The described theoretical framework served as basis for establishing the main aim of the reserach, which is reflected in determining the impact of online travel agencies on the business and profitability of hotels in Bosnia and Herzegovina.

With respect to the main aim of the research, the following hypotheses were defined:

H1: Hotels' cooperation with online travel agencies contributes to a decrease in hotels' costs.

H2: Hotels' cooperation with online travel agencies contributes to the improvement in hotels' revenues.

\section{Research methodology}

The first step in defining research is determining the target population. Accordingly, it was determined that the research should cover all the hotels in Bosnia and Herzegovina. The empirical research made use of the survey questionnaire which was developed based on the questionnaire for identifying the impact of online travel agencies that provide online booking services on hotels' profitability, by Caliskan (2013) and Šiško (2013). An appropriate sample was used during the research. A sample of 100 hotels was defined.

The questionnaire consisted of 14 questions, grouped in three appropriate groups:

1. Information on hotel's characteristics - size, category, number of rooms (Šiško, 2013);

2. Use of the Internet for distribution and cooperation with online travel agencies by the hotel - own website, questions on the cooperation with OTAs, the most popular OTAs, sources of booking, share of bookings by OTAs in the total bookings in the past year, criteria for the selection of OTA (Šiško, 2013);

3. Impact of cooperation with OTAs on the structure of hotel's costs and revenues, as well as on total effects achieved by hotels through cooperation with OTAs (Caliskan et al., 2013). This group of questions actually includes research questions of this paper that should be checked and tested.

The questionnaire was mostly conceived based on close-end questions, where the respondents chose one of the offered responses that best suits their actual view. The questionnaire mostly included ordinal (Likert) scales.

By means of the drive.google.com application, an online questionnaire was created and sent to the collected e-mail addresses of hotels. In order to collect hotels' e-mail addresses, names of towns were entered in the Internet search engine Google.com and the word 'hotels' next to the name of the town (e. g. Sarajevo; hotels). Search results mostly included the hotels' websites, where it was possible to find their e-mail address and contact data. 
In this way, the planned 100 different hotels' e-mail addresses were collected. Online questionnaires were sent to the collected e-mail addresses. The final results of the sent questionnaires included 58 usable questionnaires, which is the return rate of $58 \%$. As an explanation of why the return rate is not higher, it can be said that the return rate is generally lower in case of online surveys than in other ways of collecting data.

The structure of sample by the number of rooms, number of beds and category is presented below.

Tab. 1: Number of rooms in hotels

\begin{tabular}{l|c|c}
\multirow{2}{*}{ Number of rooms in hotel } & \multicolumn{2}{|c}{ Respondents } \\
\cline { 2 - 3 } & No. & $\%$ \\
\hline from 10 to 59 rooms & 31 & 53,4 \\
\hline from 60 to 99 rooms & 16 & 27,6 \\
\hline from 100 to 139 rooms & 1 & 1,7 \\
\hline from 140 to 179 rooms & 3 & 5,2 \\
\hline from 180 to 209 rooms & 3 & 5,2 \\
\hline 210 and more rooms & 4 & 6,9 \\
\hline TOTAL & $\mathbf{5 8}$ & $\mathbf{1 0 0}$
\end{tabular}

Tab. 2: Hotel size by the number of beds

\begin{tabular}{l|c|c}
\multirow{2}{*}{\multicolumn{2}{c}{ Hotel size }} & \multicolumn{2}{c}{ Respondents } \\
\cline { 2 - 3 } & No. & $\%$ \\
\hline Up to 100 beds & 25 & 43,1 \\
\hline Up to 300 beds & 27 & 46,6 \\
\hline Up to 400 beds & 6 & 10,3 \\
\hline TOTAL & $\mathbf{5 8}$ & $\mathbf{1 0 0}$
\end{tabular}

Tab. 3: Hotel category based on the number of stars

\begin{tabular}{l|c|c}
\multirow{2}{*}{ Hotel category } & \multicolumn{2}{c}{ Respondents } \\
\cline { 2 - 3 } & No. & $\%$ \\
\hline 1 star & 0 & 0 \\
\hline 2 stars & 2 & 3,4 \\
\hline 3 stars & 27 & 46,6 \\
\hline 4 stars & 27 & 46,6 \\
\hline 5 stars & 2 & 3,4 \\
\hline TOTAL & $\mathbf{5 8}$ & $\mathbf{1 0 0}$
\end{tabular}


Out of the 58 collected responses, 55 hotels replied that they cooperate with online travel agencies, while three responded that they do not. Respondents who do not cooperate with OTAs are included only in the analysis of research sample, while they are excluded from further analyses.

\section{Results and Discussion}

In order to test the asked research questions, the hypotheses on the impact of cooperation with OTAs on the structure of costs and revenues, and on the total effects achieved by hotels were tested using the descriptive analysis.

H1: Hotels' cooperation with online travel agencies contributes to the decrease in hotels' costs.

The text below analyzes responses relating to the research question: „Impact of hotels' cooperation with online travel agencies on the decrease in costs?" To this purpose, a scale was constructed that consisted of four questions where hotel managers were supposed to give their opinions on the level of agreement with the offered statements relating to the decrease in costs due to their cooperation with OTAs, with the help of Likert scale consisting of five levels of agreement.

Results of respondents' estimates about the OTAs impact on the structure of hotels' costs revealed that most respondents believe that their hotels have not yet experienced significant effects of decreasing their business costs as a result of work with online travel agencies. This is proven by the data that the average rating of the agreement with the statement that costs per room decreased amounted to 2.05 , that labor costs decreased amunted to 1.98, and that costs of personnel training decreased was 2.00. The average rating of the agreement with the statement that advertising costs in the hotel decreased amounted to 2.16 .

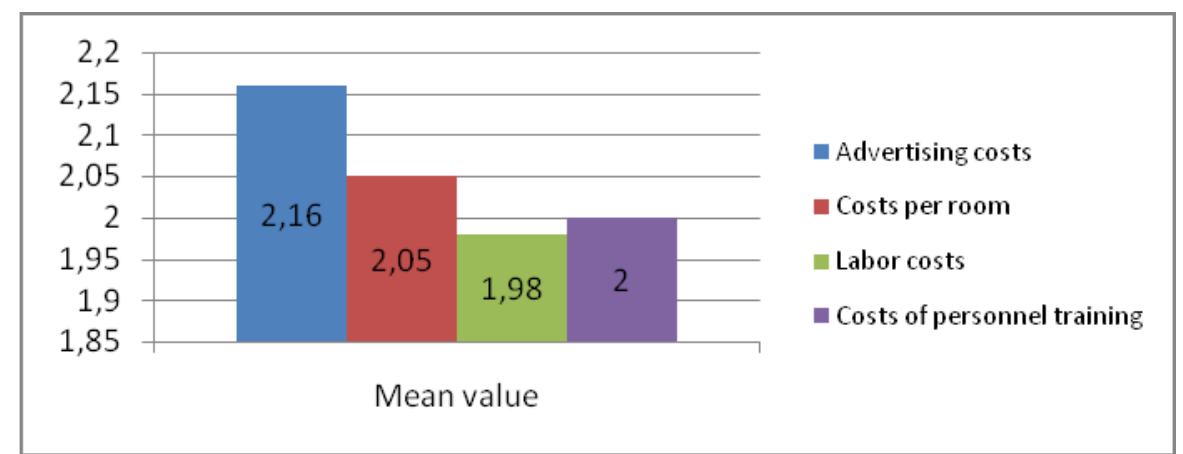

Fig. 1. Mean value of the response to question about the effect of OTAs on the structure of hotel costs

Based on the above shown, we can claim that the first hypothesis was not supported by the research, i.e. that cooperation with OTAs does not contribute to decrease in costs. It is interesting to note that the highest rating pertains to the decrease in advertising costs, which indeed is the service that hotels get from OTAs. In other words, we can claim that the total costs do not decrease significantly, but that advertising costs certainly decrease to an extent. 
H2: Hotels' cooperation with online travel agencies contributes to the improvement in hotels' revenues.

The text below analyzes responses relating to the research question: „Impact of hotels' cooperation with online travel agencies on improvements in revenues?" To this purpose as well, a scale was constructed consisting of five questions, where managers were supposed to provide the level of their agreement with offered statements pertaining to the increase in revenues due to their cooperation with OTAs, with the help of Likert scale consisting of five levels of agreement.

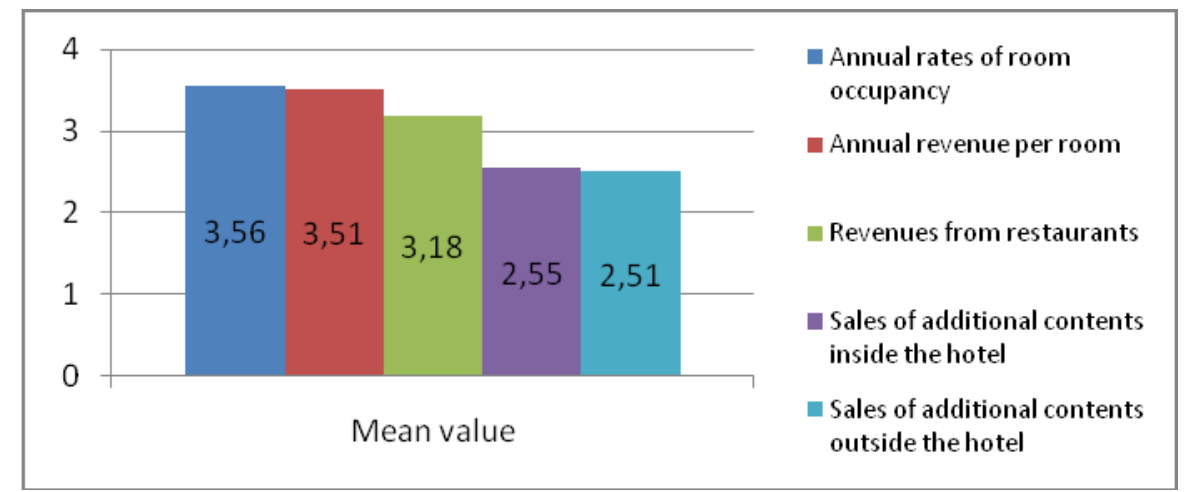

Fig. 2. Mean value of responses to the question about the impact of OTAs on improvement of revenues

Results of respondents' estimates in the context of OTAs' impact on the structure of hotels' revenues revealed that most respondents believe that the contribution of work with OTAs is reflected in the achieved increase in revenues from the sales of rooms. Other sources of revenue, such as restaurant services and additional hotel contents are not necessarily related to hotels' partnership with OTAs. This is proven by the data that the average rating of agreement with the statement that the annual revenue per room increased amounted to 3.51 , while the average rating of agreement with the statement that annual rates of room occupancy increased amounted to 3.56 .

On the other hand, with respect to revenues from restaurants and additional hotel contents inside and outside of the hotel, the average rating of agreement with the statement that revenues gained by restaurants amounted to 3.18, while average ratings of agreement with the statement that revenues from sales of additional hotel contents outside the hotel and revenues from sales of additional hotel contents inside the hotel increased amounted to 2.51 and 2.55 respectively.

Based on the above we can conclude that hotels' total revenues increase due to hotels' cooperation with OTAs, which in turn supports the second hypothesis, that hotels' cooperation with OTAs contributes to the improvement of hotels' revenues.

\section{CONCLUSION}

This research, which has the character of exploratory research, established that hotels' cooperation with online travel agencies does not conrtibute to the overall decrease in costs, but does contribute to the increase in total revenues. Online environment related to travel services creates possibilities for new players as intermediaries. Customers, hotels, as well 
as intermediaries can gain many benefits from this fruitful environment. The effect that OTAs achieved with their network makes them a good channel for consumers to buy travel products at a single central point. Besides, through cooperation with OTAs hotels achieve greater competitiveness and advantage related to reaching a larger consumer base and creating greater visibility in this environment.

It should be noted that there are not sufficient studies on this topic in Bosnia and Herzegovina, and it can be expected that this paper will open the door for further research and motivate other researchers to contribute to the development of relations between OTAs and hotels in Bosnia and Herzegovina. As a recommendation for further research, one can mention research into the dynamism of link between these subjects on the continuous basis, so that the win-win scenario between them could be developed in the future.

\section{REFERENCES:}

1. Bigne E. (2011), Strategic Management in Tourism: The Transformation of Distribution Channels, Oxfordshire, UK, 2 izdanje, str 141-157, available at http://www.books.google.ba (Accessed on August 10th, 2014.)

2. Buhalis D. (2000), Marketing the competitive destination of the future, Tourism Management, pp. 97-116

3. Buhalis D. (2000), Relationships in the Distribution Channel of Tourism: Conflict Between Hoteliers and Tour Operators in the Mediterranean Region, Haworth Press, Inc, pp. 113-139

4. Buhalis D. i Law R. (2008), Progress in information techonology and tourism management: 20 years on and 10 years after the Internet - The state of eTourism research, International Centre for Tourism and Hospitality Research, pp. 609-623

5. Caliskan, S., Kutlu, B., Kimiloglu, H. (2013), The Contribution of Online Travel Agencies to the Profitability of Hotels: Case of Turkey, Interdisciplinary Journal of Research in Business, Vol. 3, Issue. 03 pp. 08- 18

6. Connolly D. J. (1999), Understanding information technology investment decisionmaking in the context of hotel global distribution systems: A multiple-case study, Hotel and Tourism Management, Blacksburg, Virginia

7. Gursoy D. (2010), Chaotic changes in distribution channels: implications for hospitality companies, European Journal of Tourism, Hospitality and Recreation, pp. 126-137

8. Morosan C. and Jeong M. (2007), Making Hotel Reservations online: A content analysis of U.S. Travelers' Comments, Journal of Tourism, pp. 5-10

9. O'Connor P. and Frew A. J. (2004), An evaluation methodology for hotel electronic channels of distribution, Internation Journal of Hospitality Management, pp. 179-199

10. Pearce D.G. (2007), A needs-functions model of tourism distribution, Victoria University of Wellington, New Zealand, pp. 148-168

11. Šiško, A. (2013), Analiza utjecaja on-line putničkih agencija na poslovanje van sezone u RH, Ekonomski fakultet Split, pp. 71-75 